\title{
Phosphinate-containing heterocycles: A mini-review
}

\author{
Olivier Berger and Jean-Luc Montchamp*
}

\author{
Review \\ Address: \\ Department of Chemistry, Box 298860, Texas Christian University, \\ Fort Worth, Texas 76129, USA

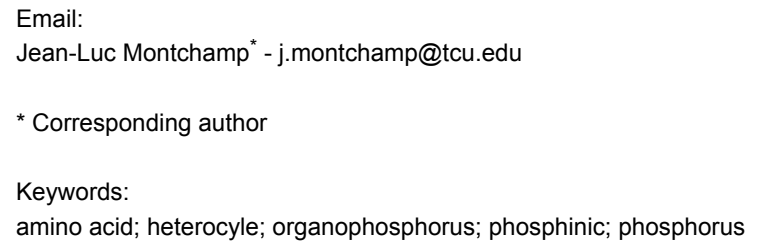

Beilstein J. Org. Chem. 2014, 10, 732-740.

doi:10.3762/bjoc. 10.67

Received: 20 December 2013

Accepted: 05 March 2014

Published: 27 March 2014

This article is part of the Thematic Series "Organophosphorus chemistry".

Guest Editor: P. R. Hanson

(C) 2014 Berger and Montchamp; licensee Beilstein-Institut. License and terms: see end of document.

\begin{abstract}
This review provides an overview of recent efforts towards the synthesis of phosphinate heterocycles $\mathrm{R}^{1} \mathrm{R}^{2} \mathrm{P}(\mathrm{O})(\mathrm{OR})$. Our laboratory and others' have been involved in this field and as a result new $\mathrm{P}-\mathrm{C}, \mathrm{P}-\mathrm{N}$, and $\mathrm{P}-\mathrm{O}$ containing heterocyclic motifs are now available through a variety of methods. While developing rapidly, this area is still in its infancy so that biological testing of the compounds has not yet been conducted and applications are rare. The growing availability of synthetic methods will undoubtedly change this situation in the near future.
\end{abstract}

\section{Introduction}

The preparation of P-heterocycles has been the subject of many studies over the years, and the field has been extensively reviewed [1-8]. Typically, accessing $P$-heterocycles involves multistep sequences with low overall yields [1-8]. In the past 20 years, significant effort has been devoted to synthetic and reactivity studies of a particular family of organophosphorus compounds: the phosphinates $\mathrm{R}^{1} \mathrm{R}^{2} \mathrm{P}(\mathrm{O})(\mathrm{OR})$ [9]. Because the phosphinic acid moiety $\mathrm{P}(\mathrm{O}) \mathrm{OH}$ can mimic carboxylic acids, its incorporation into heterocycles may offer new opportunities for the discovery of biologically active analogs. However, little or no biological data is available at this time. Selected recent synthetic work by us and others is presented below.

\section{Review}

\section{Phospholes}

Several compounds have been prepared in this series. Keglevich and coworkers realized the synthesis of phosphole derivatives 2a-f based on the McCormack reaction [10] followed by microwave-assisted esterification of the phosphinic acid using different alcohols in large excess (Scheme 1) $[11,12]$. Six phospholes 2 a-f were prepared in yields up to $94 \%$.

Montchamp and coworkers have synthesized phospholes 4a,b by ring closing metathesis using 2 or $5 \mathrm{~mol} \%$ of $2^{\text {nd }}$ generation Grubbs' catalyst (Scheme 2) [13,14]. Two compounds 4a,b 


\begin{tabular}{|c|c|c|}
\hline \multirow{2}{*}{$\left.\right|_{1 \mathbf{a}-\mathbf{f}} ^{\mathrm{Re}}$} & $\begin{array}{l}\text { 1) } \mathrm{PBr}_{3} \\
\text { 2) } \mathrm{H}_{2} \mathrm{O}\end{array}$ & \multirow{2}{*}{ 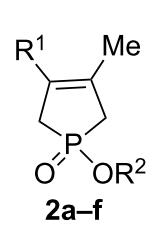 } \\
\hline & $\begin{array}{l}\text { 3) } \mathrm{R}_{2} \mathrm{OH} \text { (15 equiv) } \\
\mu \mathrm{w},>200^{\circ} \mathrm{C}\end{array}$ & \\
\hline \multicolumn{2}{|c|}{$\begin{array}{l}\mathrm{R}^{1}=\mathrm{H}, \mathrm{Me} \\
\mathrm{R}^{2}=n-\mathrm{C}_{5} \mathrm{H}_{11} \quad \mathrm{iC}_{5} \mathrm{H}_{11} \text { 2-ethylhexyl }\end{array}$} & $\begin{array}{c}57-94 \% \\
6 \text { examples }\end{array}$ \\
\hline \multicolumn{3}{|c|}{ Scheme 1: McCormack synthesis. } \\
\hline
\end{tabular}

were prepared in $51 \%$ and $62 \%$ yields. The same approach was reported earlier by Mioskowski and coworkers $[15,16]$ except the starting phosphinates $\mathbf{3 a , b}$ were prepared less efficiently by the sila-Arbuzov reaction of bis(trimethylsiloxy)phosphine $\left(\mathrm{Me}_{3} \mathrm{SiO}\right)_{2} \mathrm{PH}$.

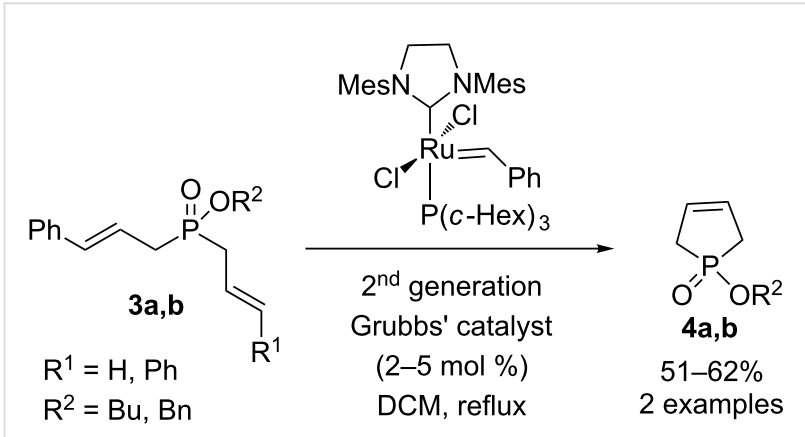

Scheme 2: Ring-closing metathesis.

\section{Phosphindoles}

Montchamp and coworkers have synthesized a few phosphindoles. The first phosphindole 6 was simply obtained in $84 \%$ yield by reacting an $\alpha, \omega$-bisphosphonate derivative 5 with $n$-butyllithium in a phospha-Dieckmann condensation (Scheme 3) [17].<smiles>CCOP(=O)(Cc1ccccc1CP(=O)(OCC)OCC)OCC</smiles>
$\frac{n \text {-BuLi (2 equiv) }}{\stackrel{\begin{array}{c}\text { THF, }-78^{\circ} \mathrm{C}, 1 \mathrm{~h} \\ \text { then } \mathrm{rt}, 1 \mathrm{~h}\end{array}}{ }}$

Scheme 3: Phospha-Dieckmann condensation

Cyclohexyl 2-(biphenyl)- $H$-phosphinate 7 was cyclized using $2 \mathrm{~mol} \%$ of $\mathrm{Pd}(\mathrm{OAc})_{2}$ in refluxing THF to produce another phosphindole 8 in $48 \%$ yield (Scheme 4) [18].

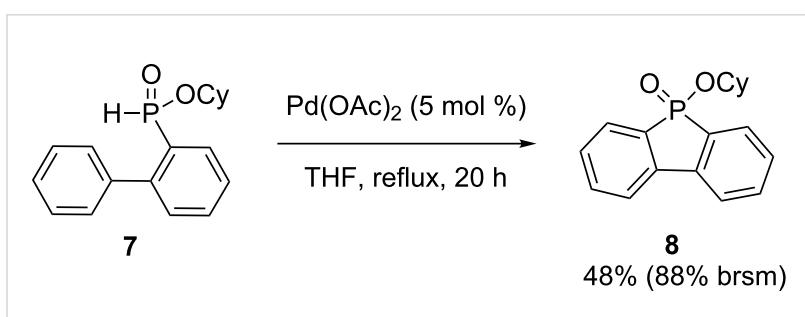

Scheme 4: Palladium-catalyzed oxidative arylation.

A phosphindol-3-one 11 was prepared in 54\% yield from butylphosphinate 9 by first methylation using DBU and iodomethane followed by a cross-coupling with ethyl 2-bromobenzoate (10) and then a Dieckmann-like condensation using LiHMDS (Scheme 5) [19].

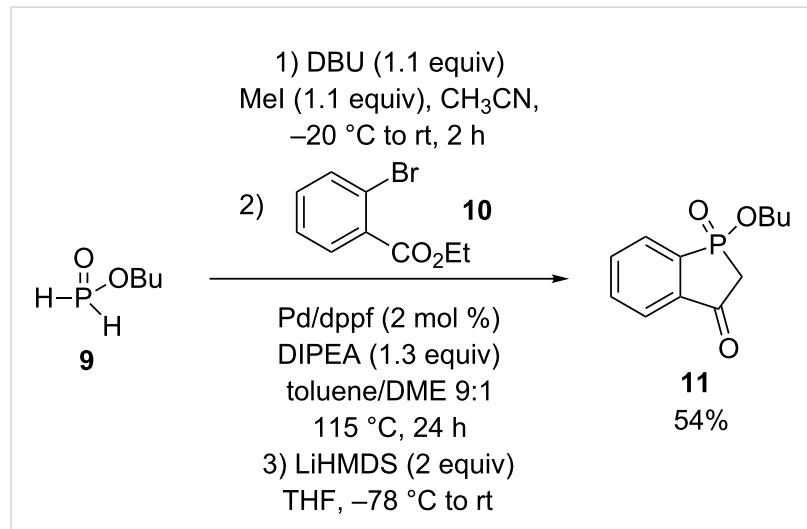

Scheme 5: Tandem cross-coupling/Dieckmann condensation.

Tanaka and coworkers have synthesized chiral benzopyrano and naphthopyrano-fused helical phosphafluorenes 14a-d from dialkynyl phosphinate $\mathbf{1 2}$ and phenol-linked terminal tetrayne 13 at room temperature for only $1 \mathrm{~h}$ using a cationic rhodium(I)/(R)-tol-BINAP complex as a catalyst. Four helical phosphafluorenes 14a-d were prepared in yields up to $40 \%$ and enantiomeric excesses up to $73 \%$ (Scheme 6) [20].

Chen and Duan have synthesized one phosphinoline 17 in $60 \%$ yield by the alkyne-arene annulation of ethyl phenyl- $H$-phosphinate (15) using 2 equivalents of $\mathrm{Ag}_{2} \mathrm{O}$ (Scheme 7) [21]. Miura et al. simultaneously reported the same reaction but with 4 equivalents of $\mathrm{AgOAc}$ instead, delivering the heterocycle 17 in 53\% yield (Scheme 8) [22]. Both reactions used 4 equivalents of $\operatorname{Ag}(\mathrm{I})$ as well as an excess of $H$-phosphinate.

\section{1,3-Oxaphospholes}

Cristau and coworkers have achieved the direct synthesis of 1,3oxaphospholes 20a-f (Scheme 9) by reacting chloroalkylphosphinic or phosphonic chlorides 18 with malonic diester 19 in the 

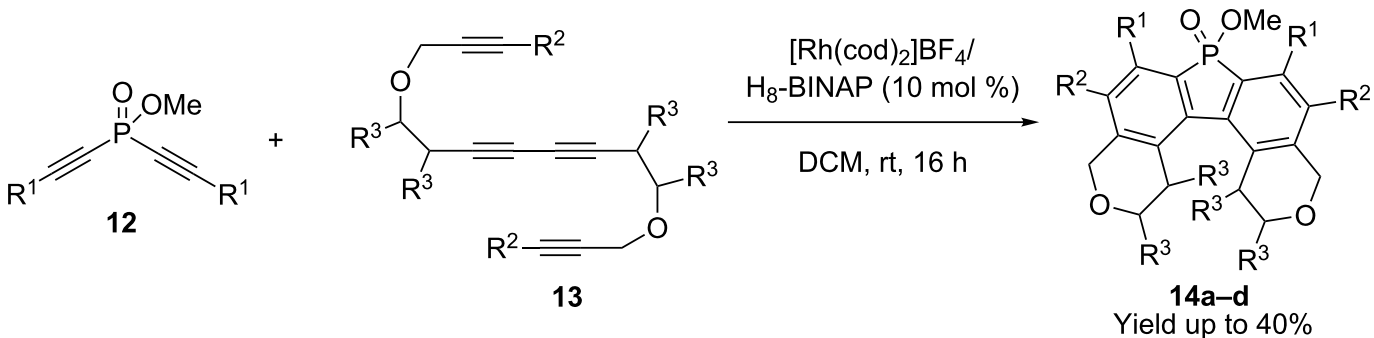

ee up to $73 \%$

Scheme 6: Rhodium-catalyzed double $[2+2+2]$ cycloaddition.

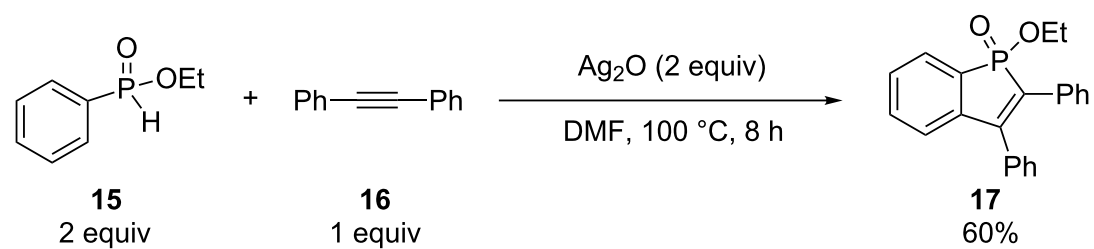

Scheme 7: Silver oxide-mediated alkyne-arene annulation.

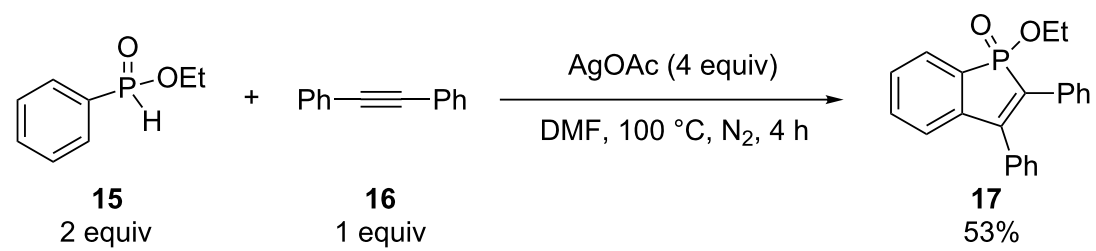

Scheme 8: Silver acetate-mediated alkyne-arene annulation.

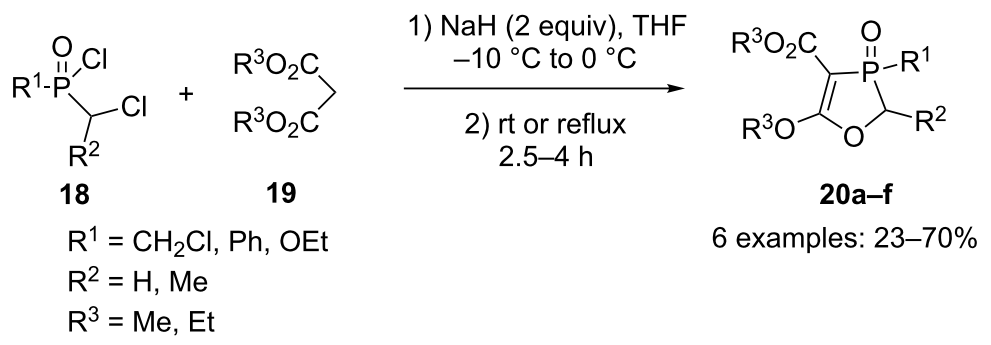

Scheme 9: Cyclization through phosphinylation/alkylation of malonate anion.

presence of two equivalents of sodium hydride [23,24]. 1,3Oxaphospholes 20a-f were obtained in yields up to $70 \%$.

\section{1-Aza-3-phospha-6-oxabicyclo[3.3.0]octanes}

The synthesis of chiral bicyclic phosphinates 23a-k by domino hydrophosphinylation/Michael/Michael reaction was realized by Fourgeaud et al. (Scheme 10) [25].

Several 1-oxa-3-aza-6-phosphabicyclo[3.3.0]octanes derivatives $\mathbf{2 3 a}-\mathbf{k}$ were obtained in yields around $70 \%$ by reacting allenes 21 with imines 22 derived from $(R)$ - or $(S)$-phenylglycinol, $(S)$-2-aminobutanol or ethanolamine. Diastereoisomeric ratios were generally close to 50:50. A model for this reaction's diastereoselectivity was proposed.

\section{Cyclo-PALA}

Montchamp and coworkers have achieved the synthesis of 5and 6-membered rings "cyclo-PALA" analogs which are 1,3azaphospholidine and 1,4-azaphosphorine derivatives 26, 29 [26]. 
<smiles></smiles>

21

$\mathrm{R}^{1}=\mathrm{Me}$, cyclopentyl

$\mathrm{R}^{2}=\mathrm{Ph}, p-\mathrm{CF}_{3} \mathrm{C}_{6} \mathrm{H}_{4}, \mathrm{iPr}$<smiles>[R]C(CO)/N=C(/O)c1ccccc1</smiles>

22<smiles>CN(C)O[Na]</smiles>

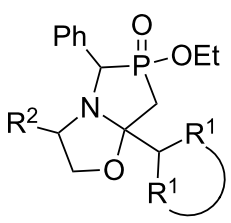

23a-k

11 examples: $45-80 \%$

Scheme 10: Tandem hydrophosphinylation/Michael/Michael reaction of allenyl- $H$-phosphinates.

For the 5-membered ring 26, hydroxymethyl- $H$-phosphinic acid (24) underwent a sila-Arbuzov reaction with the bromide $\mathbf{2 5}$, the crude mixture was esterified with diphenyldiazomethane, cyclized using Mitsunobu conditions and then hydrogenolyzed to produce the five-membered amide 26 in $22 \%$ overall yield (Scheme 11).

For the six-membered "cyclo-PALA" 29, isoprenyl- $H$-phosphinic acid (27) reacted with the bromide 25 under sila-
Arbuzov conditions, the crude phosphinic acid was esterified, using $\mathrm{BnBr} / \mathrm{Ag}_{2} \mathrm{O}$, ozonolyzed and then reduced with sodium borohydride to afford an alcohol intermediate 28. This product was cyclized using Mitsunobu conditions and finally hydrogenolyzed to deliver the 6-membered heterocycle $\mathbf{2 9}$ in $12 \%$ overall yield (Scheme 12) [26].

In this particular study phosphinates $\mathbf{2 6}$ and $\mathbf{2 9}$ were tested as inhibitors of aspartate transcarbamoylase (ATCase).

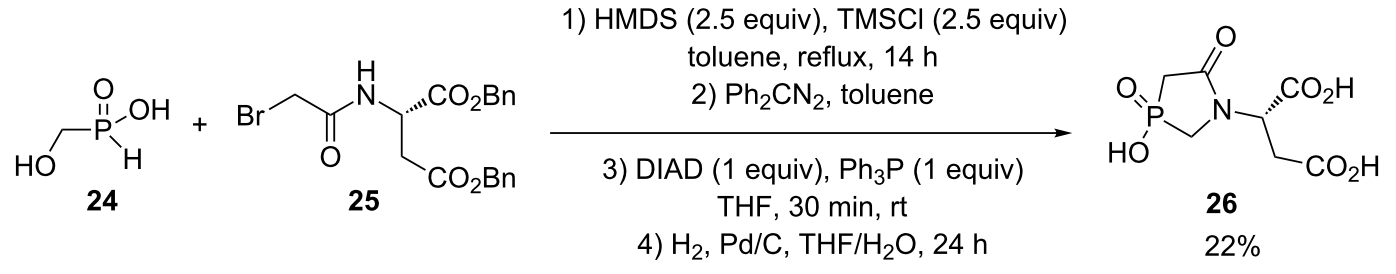

Scheme 11: 5-Membered "cyclo-PALA" via intramolecular Mitsunobu reaction.

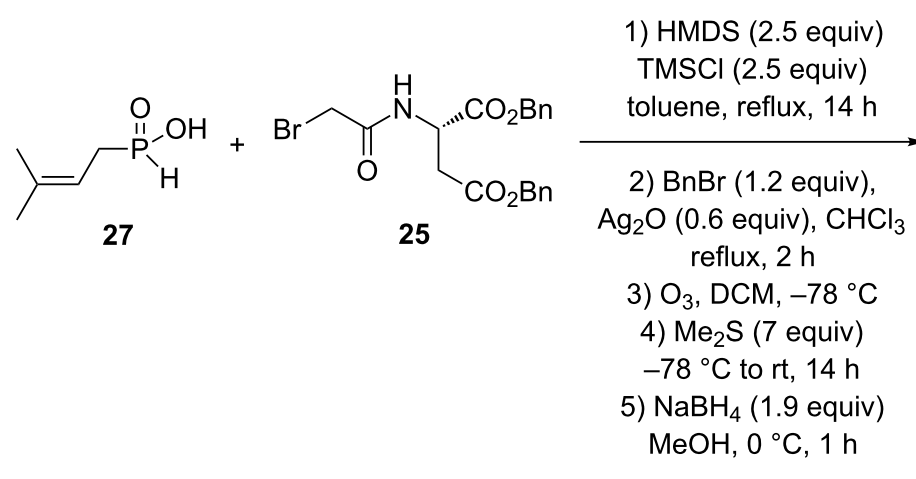

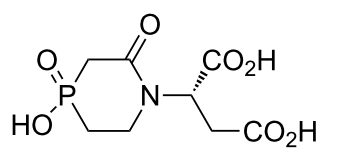

29 
5-Membered 26 was completely inactive, whereas 6-membered 29 showed modest activity $\left(K_{\mathrm{i}}=1 \mu \mathrm{M}, 63\right.$ times less active than phosphonic acid $N$-phosphonacetyl-L-aspartate PALA, $\left.K_{\mathrm{i}}=16 \mathrm{nM}\right)$.

\section{1,3-Azaphosphorines and 1,3-azaphospho- lidines}

Several 1,3-azaphosphorines and 1,3-azaphospholidines were synthesized by Montchamp and coworkers. The reaction of 2-aminoethyl- $H$-phosphinate 30a $(n=1)$ with carbonyl compounds 31 in refluxing butanol or concentrated hydrochloric acid took place smoothly to generate seven 1,3-azaphospholidines 32a-g in yields up to 55\% (Scheme 13) [27,28].

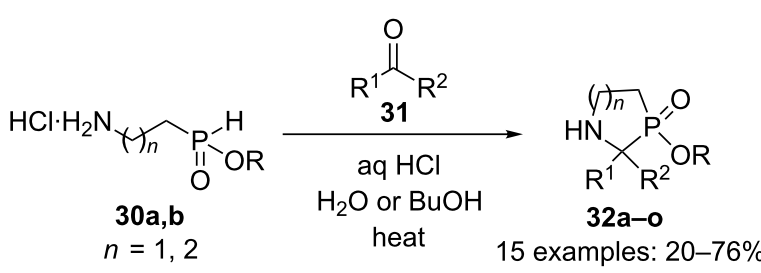

Scheme 13: Intramolecular Kabachnik-Fields reaction.

The reaction of 3-aminopropyl- $H$-phosphinate $30 \mathbf{b}$ with aldehydes 31 in refluxing butanol allowed the formation of eight 1,3-azaphosphorines $\mathbf{3 2} \mathbf{h}-\mathbf{o}$ in yields up to $76 \%$ (Scheme 13).

Montchamp and coworkers also prepared two other examples of 1,3 -azaphosphorines $\mathbf{3 5 a} \mathbf{a}, \mathbf{b}(n=1)$ in yields up to $61 \%$ by reacting ethyl-3-chloropropyl- $H$-phosphinate 33 with imines 34 in toluene at reflux (Scheme 14) [29].

\section{1,3-Azaphosphindoles and 1,3-benzazaphos- phorines}

Several compounds in this series were synthesized by Montchamp and coworkers using two different approaches. The first one is the reaction between an imine 34 and 2-bromophenyl-substituted $H$-phosphinate esters 36 in the presence of $\mathrm{Cs}_{2} \mathrm{CO}_{3}$, and catalytic $\mathrm{Pd}\left(\mathrm{PPh}_{3}\right)_{4}$ in refluxing toluene to generate the corresponding cyclized products $37 \mathbf{a}-\mathbf{h}$ in yields up to $76 \%$ (Scheme 15) [29].

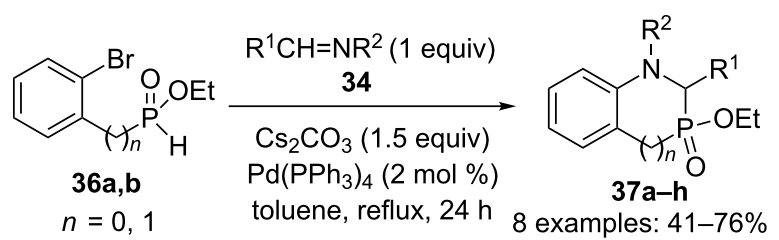

Scheme 15: Tandem Kabacknik-Fields/C-N cross-coupling reaction.

The second way is the formation of the imine first by reacting an amine 39a,b with an aldehyde $\mathbf{3 8}$, then the phosphinate is introduced and the mixture stirred for $24 \mathrm{~h}$ at reflux to generate the corresponding $H$-phosphinate esters. Addition of DIPEA and catalytic $\mathrm{Pd} / \mathrm{dppf}$ in a mixture DMF/DME to the intermediates generated the corresponding cyclized derivatives $\mathbf{4 0 a}, \mathbf{b}$ in yields up to $53 \%$ (Scheme 16) [18].

$$
\begin{aligned}
& n=1,2 \\
& \mathrm{X}=\mathrm{Cl} \text { or } \mathrm{Br} ; \mathrm{R}^{1}=\mathrm{H}, \mathrm{Ph} ; \mathrm{R}^{2}=\mathrm{Bn}, \mathrm{Ph}
\end{aligned}
$$

\section{toluene \\ reflux, $16 \mathrm{~h}$}

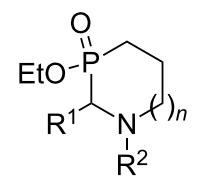

35a-d

4 examples: $45-76 \%$

Scheme 14: Tandem Kabachnik-Fields/alkylation reaction.

1) neat, $1 \mathrm{~h}$<smiles>O=Cc1ccccc1</smiles>

38<smiles>[X]c1ccccc1NN</smiles>

39a,b
2) $\mathrm{CyOP}(\mathrm{O}) \mathrm{H}_{2}$ (1.3 equiv) toluene, reflux, $24 \mathrm{~h}$

3) Pd/dppf (2 mol \%) DIPEA ( 1.3 equiv) DMF/DME 9:1 $115^{\circ} \mathrm{C}, 24 \mathrm{~h}$<smiles>O=P1(OC2CCCCC2)c2ccccc2[Y10]NC1c1ccccc1</smiles>

40a,b

$n=0: 33 \%+20 \%$

$n=1: 25 \%+21 \%$ 
For these compounds, the authors were able to separate the different diastereoisomers generated during the reaction by simple column chromatography on silica gel.

\section{1,4-Azaphosphorines}

In this series, only a few examples have been reported in the literature. One derivative has been prepared by Manthey and coworkers in $50 \%$ yield as a precursor to a dihydroorotase inhibitor (Scheme 17) [30].

In this example, the amino acid $\mathbf{4 1}$ was first cyclized using 1-(3dimethylaminopropyl)-3-ethylcarbodiimide (42) at pH 5.6 followed by protection of the carboxylic acid and phosphinic acid moieties by diphenylmethyl group using a slight excess of diphenyldiazomethane. The two diastereoisomers obtained were readily separable by column chromatography.

Another example has been synthesized in $45 \%$ yield by Montchamp and coworkers (Scheme 18) [14].

To prepare the required phosphinate $\mathbf{4 5}$ a double allylation of $\mathrm{H}_{3} \mathrm{PO}_{2}$ was performed using 2 equivalents of cinnamyl alcohol 44 in the presence of $2 \mathrm{~mol} \%$ of Pd/Xanthpos followed by an esterification using benzyl bromide. Ozonolysis, and reductive amination using excess benzylamine in the presence of sodium cyanoborohydride completed the synthesis.

\section{Phosphorines}

Two phosphorines 47a,b were obtained by Montchamp and coworkers via the cyclization of 5-bromopentyl- $H$-phosphinate esters 46a,b in the presence of LiHMDS in 71\% and 74\% yields for the butyl and ethyl esters respectively (Scheme 19) [28,31].

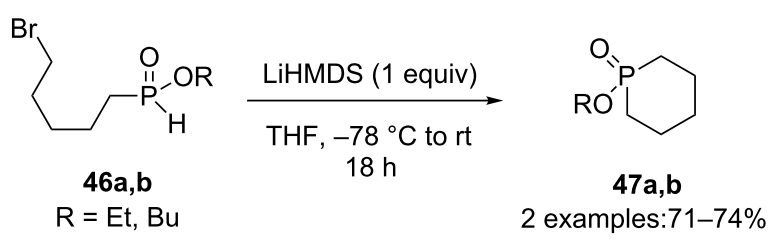

Scheme 19: H-Phosphinate alkylation.

Another phosphorine 49 was obtained by Montchamp and coworkers in $57 \%$ yield via the cyclization through conjugate addition of ethyl 7-(ethoxy- $H$-phosphinoyl)-3-methyl-2heptenoate (48) in the presence of potassium tert-butoxide (Scheme 20) [28].

A phosphorino[3', 4':4,5]furo[2,3- $d]$-1,3-dioxole 51 was synthesized in $36 \%$ yield by Tattersall and coworkers by realizing a double Arbuzov-type reaction between bis(trimethylsiloxy)phosphine and the dibromide $\mathbf{5 0}$ followed by the esterification of the phosphinic acid using diazomethane (Scheme 21)

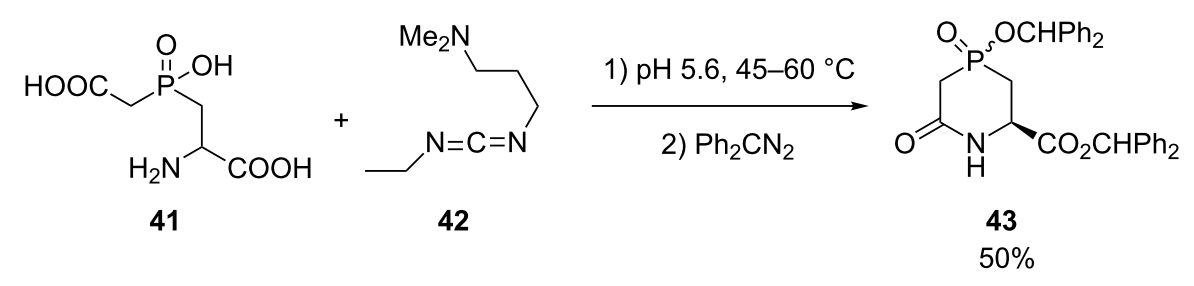

Scheme 17: Heterocyclization via amide formation.

1) $\mathrm{H}_{3} \mathrm{PO}_{2}$ (1 equiv), $\mathrm{Pd}_{2} \mathrm{dba}_{3}(1 \mathrm{~mol} \%)$ Xantphos (2 mol \%), $t$-AmOH, $100{ }^{\circ} \mathrm{C}, 24 \mathrm{~h}$

2) $\mathrm{BnBr}$ (2 equiv), $\mathrm{Ag}_{2} \mathrm{O}$ (1.6 equiv)

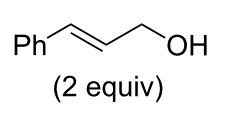

44 $\mathrm{CHCl}_{3}$, reflux

3) $\mathrm{O}_{3}, \mathrm{DCM}, \mathrm{Me}_{2} \mathrm{~S}$

4) $\mathrm{BnNH}_{2} \cdot \mathrm{HCl}$ (3 equiv), $\mathrm{Et}_{3} \mathrm{~N}$ (3 equiv)

$\mathrm{NaBH}_{3} \mathrm{CN}$ (4.8 equiv), $\mathrm{CH}_{3} \mathrm{CN}$

$\mathrm{AcOH}$ to $\mathrm{pH} 4-5$

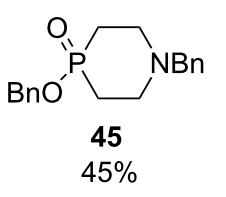

$45 \%$ 


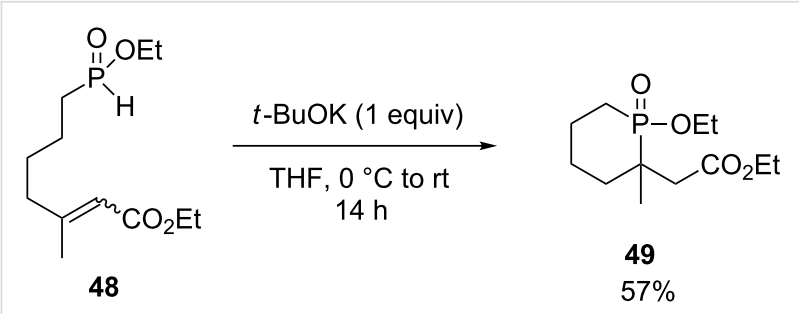

Scheme 20: Cyclization through intramolecular Michael addition.

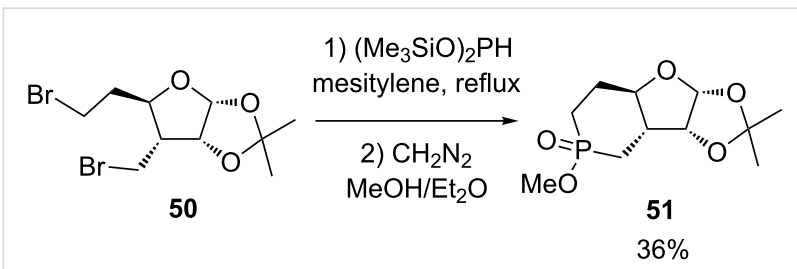

Scheme 21: Double Arbuzov reaction of bis(trimethylsiloxy)phosphine.

[32]. The heterocyclization step followed methodology initially introduced by Frost et al [33].

Compound 51 was subsequently converted into the corresponding analog of cyclic AMP, but no biological activity was reported.

\section{1,2-Oxaphosphorines}

Gouverneur and coworkers have realized the synthesis of several 1,2-oxaphosphorine derivatives 53a-k using diastereoselective ring closing metathesis with 2 to $4 \mathrm{~mol} \%$ of various catalysts (Scheme 22) [34].

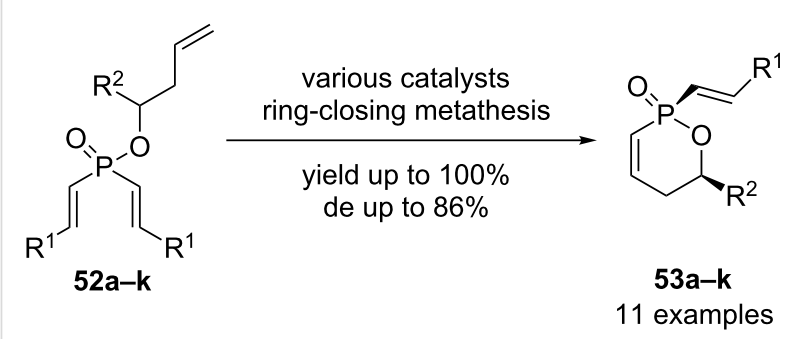

Scheme 22: Diastereoselective ring-closing metathesis.
During this work, they obtained 11 different compounds in yields up to $100 \%$ and diastereomeric excesses up to $86 \%$. The starting phosphinates $\mathbf{5 2} \mathbf{a}-\mathbf{k}$ were prepared using classical chemistry involving Grignard addition to $\operatorname{EtOP}(\mathrm{O}) \mathrm{Cl}_{2}$.

\section{Phenoxaphosphine}

Scheme 23 shows the synthesis of one phenoxaphosphine 56 in $55 \%$ yield by $\mathrm{Li}$ and coworkers via the reaction between diethyl 2-oxocyclohexylphosphonate (54) and benzyne generated from 2-(trimethylsilyl)phenyl triflate (55) and cesium fluoride [35].

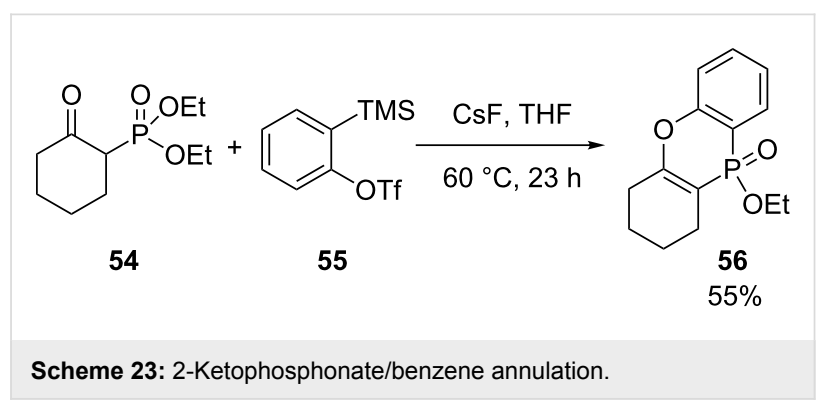

\section{1,4,2-Oxazaphosphinane}

This series of compounds is only represented by few examples all generated through methodology developed by Pirat and coworkers. Scheme 24 shows the synthesis of a $H$-phosphinate intermediate 59 in $65 \%$ yield via the reaction between the imine 57 of the racemic 1,2-diphenylethanolamine with benzaldehyde and methyl phosphinate (58) followed by the cyclization through a base catalyzed transesterification $[23,36]$.

This versatile intermediate $\mathbf{5 9}$ was reacted with aldehydes, imines, olefins and aryl bromides or aryl iodides to generate a wide range of phosphinates.

The same authors have also prepared another $H$-phosphinate intermediate $\mathbf{6 1}$ in $71 \%$ yield (Scheme 25) [37].

This oxazaphosphinane $\mathbf{6 1}$ was synthesized in two steps at room temperature, first, by a nucleophilic attack of methyl hypophosphite on oxazolidine $\mathbf{6 0}$ followed by an intramolecular cyclization, this time without base catalyzed transesterification. The authors explained this difference of reactivity by the

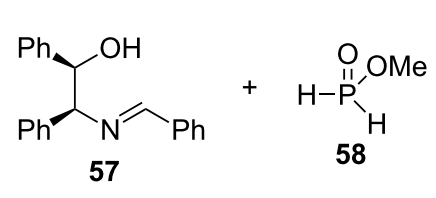

57

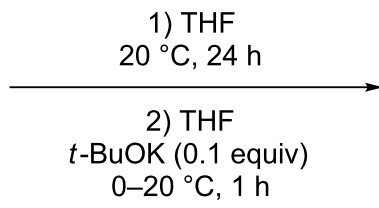

$0-20^{\circ} \mathrm{C}, 1 \mathrm{~h}$

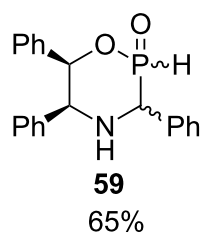




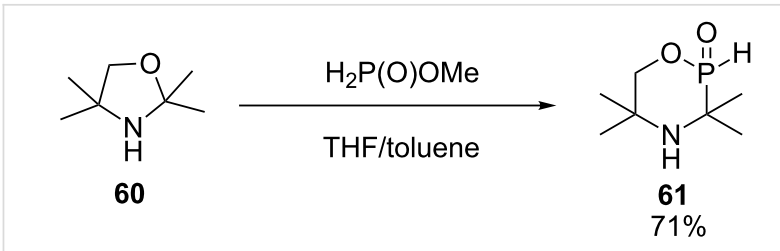

Scheme 25: Tandem Kabachnik-Fields/transesterification reaction with oxazolidine.

Thorpe-Ingold effect [38]. Indeed, the presence of four methyl groups allows the hydroxy function to be spatially closer to the reactive phosphinate, facilitating the intramolecular cyclization of this product.

\section{Conclusion}

Phosphinate heterocycles are becoming routine products in the literature. Classical approaches such as the McCormack reaction of conjugated dienes, the sila-Arbuzov reaction of bis(trimethylsiloxy)phosphine with dihalides, etc. continue to be useful. However, novel approaches in both the preparation of acyclic precursors and the reactions to achieve their heterocyclization, have led to more efficient synthesis and broader structural diversity. While, like with any other P-heterocycles the phosphinates can be employed for the synthesis of novel phosphine ligands, their potential for the discovery of novel biologically active motifs is tantalizing.

\section{Acknowledgements}

This material is based in part upon work supported by the National Science Foundation under Grant No. 1262254. We also acknowledge the following coworkers for prior contributions to this field: Laëtitia Coudray, Patrice Ribière, Clemence Queffélec, Isabelle Abrunhosa-Thomas, Christelle Petit, Laurent Gavara, Stephanie Ortial, Henry C. Fisher, Fabien Gelat, and Karla Bravo-Altamirano.

\section{References}

1. Mathey, F., Ed. Phosphorus-Carbon Heterocyclic Chemistry: The Rise of a New Domain; Elsevier: Oxford, 2001.

2. Quin, L. D. A Guide to Organophosphorus Chemistry; John Wiley and Sons: New York, 2000.

3. Dillon, K. B.; Mathey, F.; Nixon, J. F. Phosphorus: the Carbon Copy; John Wiley and Sons: Chichester, 1998.

4. Katritzky, A. R.; Rees, C. W.; Scriven, E. F. C., Eds. Comprehensive Heterocyclic Chemistry II; Pergamon: New York, 1996.

5. Mathey, F. Chem. Rev. 1990, 90, 997-1025. doi:10.1021/cr00104a004

6. Quin, L. D. The Heterocyclic Chemistry of Phosphorus; John Wiley and Sons: Chichester, 1981.

7. Venkataramu, S. D.; MacDonell, G. D.; Purdum, W. R.; El-Deek, M.; Berlin, K. D. Chem. Rev. 1977, 77, 121-181. doi:10.1021/cr60306a001

8. Berlin, K. D.; Hellwege, D. M. Top. Phosphorus Chem. 1969, 6, 1-186.

9. Montchamp, J.-L. Acc. Chem. Res. 2014, 47, 77-87. doi:10.1021/ar400071v
10. McCormack, W. B. Org. Synth. 1973, 5, 787.

11. Kiss, N. Z.; Böttger, E.; Drahos, L.; Keglevich, G. Heteroat. Chem. 2013, 24, 283-288. doi:10.1002/hc.21092

12. Keglevich, G.; Kiss, N. Z.; Mucsi, Z.; Körtvélyesi, T. Org. Biomol. Chem. 2012, 10, 2011-2018. doi:10.1039/c2ob06972e

13. Bravo-Altamirano, K.; Abrunhosa-Thomas, I.; Montchamp, J.-L. J. Org. Chem. 2008, 73, 2292-2301. doi:10.1021/jo702542a

14. Coudray, L.; Bravo-Altamirano, K.; Montchamp, J.-L. Org. Lett. 2008, 10, 1123-1126. doi:10.1021/ol8000415

15. Bujard, M.; Gouverneur, V.; Mioskowski, C. J. Org. Chem. 1999, 64, 2119-2123. doi:10.1021/jo981795j

16. Briot, A.; Bujard, M.; Gouverneur, V.; Nolan, S. P.; Mioskowski, C. Org. Lett. 2000, 2, 1517-1519. doi:10.1021/ol005651e

17. Gavara, L.; Gelat, F.; Montchamp, J.-L. Tetrahedron Lett. 2013, 54, 817-820. doi:10.1016/j.tetlet.2012.11.119

18. Berger, O.; Petit, C.; Deal, E. L.; Montchamp, J.-L. Adv. Synth. Catal. 2013, 355, 1361-1373. doi:10.1002/adsc.201300069

19. Gavara, L.; Petit, C.; Montchamp, J.-L. Tetrahedron Lett. 2012, 53, 5000-5003. doi:10.1016/j.tetlet.2012.07.019

20. Fukawa, N.; Osaka, T.; Noguchi, K.; Tanaka, K. Org. Lett. 2010, 12, 1324-1327. doi:10.1021/ol100227k

21. Chen, Y.-R.; Duan, W.-L. J. Am. Chem. Soc. 2013, 135, 16754-16757. doi:10.1021/ja407373g

22. Unoh, Y.; Hirano, K.; Satoh, T.; Miura, M. Angew. Chem., Int. Ed. 2013, 52, 12975-12979. doi:10.1002/anie.201307211

23. Cristau, H.-J.; Pirat, J.-L.; Virieux, D.; Monbrun, J.; Ciptadi, C.; Bekro, Y.-A. J. Organomet. Chem. 2005, 690, 2472-2481. doi:10.1016/j.jorganchem.2004.11.035

24. Virieux, D.; Ciptadi, C.; Bekro, Y.-A.; Cristau, H.-J. Eur. J. Org. Chem. 2004, 3205-3211. doi:10.1002/ejoc.200400179

25. Fourgeaud, P.; Daydé, B.; Volle, J.-N.; Vors, J.-P.; Van der Lee, A.; Pirat, J.-L.; Virieux, D. Org. Lett. 2011, 13, 5076-5079. doi:10.1021/ol2019345

26. Coudray, L.; Pennebaker, A. F.; Montchamp, J.-L. Bioorg. Med. Chem. 2009, 17, 7680-7689. doi:10.1016/j.bmc.2009.09.045

27. Queffélec, C.; Ribière, P.; Montchamp, J.-L. J. Org. Chem. 2008, 73, 8987-8991. doi:10.1021/jo801768y

28. Ortial, S.; Fisher, H. C.; Montchamp, J.-L. J. Org. Chem. 2013, 78, 6599-6608. doi:10.1021/jo4008749

29. Queffélec, C.; Montchamp, J.-L. Org. Biomol. Chem. 2010, 8, 267-273. doi:10.1039/b917428a

30. Manthey, M. K.; Huang, D. T. C.; Bubb, W. A.; Christopherson, R. I. J. Med. Chem. 1998, 41, 4550-4555. doi:10.1021/jm970814z

31. Abrunhosa-Thomas, I.; Sellers, C. E.; Montchamp, J.-L. J. Org. Chem. 2007, 72, 2851-2856. doi:10.1021/jo062436o

32. Regan, A. C.; Sciammetta, N.; Tattersall, P. I. Tetrahedron Lett. 2000, 41, 8211-8215. doi:10.1016/S0040-4039(00)01437-4

33. Montchamp, J.-L.; Tian, F.; Frost, J. W. J. Org. Chem. 1995, 60, 6076-6081. doi:10.1021/jo00124a018

34. Dunne, K. S.; Bisaro, F.; Odell, B.; Paris, J.-M.; Gouverneur, V. J. Org. Chem. 2005, 70, 10803-10809. doi:10.1021/jo0518708

35. Liu, Y.-L.; Liang, Y.; Pi, S.-F.; Li, J.-H. J. Org. Chem. 2009, 74, 5691-5694. doi:10.1021/jo900847u

36. Cristau, H.-J.; Monbrun, J.; Tillard, M.; Pirat, J.-L. Tetrahedron Lett. 2003, 44, 3183-3186. doi:10.1016/S0040-4039(03)00446-5

37. Volle, J.-N.; Kaloyanov, N.; Saada, M. C.; Virieux, D.; Pirat, J.-L. Tetrahedron Lett. 2007, 48, 4695-4697. doi:10.1016/j.tetlet.2007.05.014

38. Jung, M. E.; Piizzi, G. Chem. Rev. 2005, 105, 1735-1766. doi:10.1021/cr940337h 


\section{License and Terms}

This is an Open Access article under the terms of the Creative Commons Attribution License

(http://creativecommons.org/licenses/by/2.0), which permits unrestricted use, distribution, and reproduction in any medium, provided the original work is properly cited.

The license is subject to the Beilstein Journal of Organic Chemistry terms and conditions:

(http://www.beilstein-journals.org/bjoc)

The definitive version of this article is the electronic one which can be found at:

doi:10.3762/bjoc. 10.67 